\title{
Comparative study of pain perception in outpatient hysteroscopy analyzing previous orientation by multimedia
}

\author{
Walter Antônio Prata Pace ${ }^{1,2 *}$, Ana Luiza Loiola Pace ${ }^{3}$, Andréa Alves Morato', \\ Francisco de Assis Nunes Pereira ${ }^{1,2}$, Gabriela Loiola Pace1, João Oscar de Almeida Falcão Junior ${ }^{1,2}$ \\ ${ }^{1}$ Faculdade Ciências Médicas de Minas Gerais (FCM-MG), Faculdade de Medicina, Belo Horizonte, MG, Brasil \\ ${ }^{2}$ Hospital Universitário Ciências Médicas de Minas Gerais (HUCM-MG), Hospital Universitário, Belo Horizonte, MG, Brasil \\ ${ }^{3}$ Pontifícia Universidade Católica de Minas Gerais (PUC-MG), Faculdade de Medicina, Betim, MG, Brasil
}

\begin{abstract}
Objectives: To evaluate the impact of previous guidance on the hysteroscopy exam using multimedia resources (film) compared to verbal orientations only, on the pain intensity perceived by the patient during hysteroscopy without anesthesia. Methods: Randomized clinical trial, which included 187 women, who were referred for hysteroscopy. The patients in the experimental group (89) watched an explanatory video just before the exam. The control group (98), however, received only routine verbal guidance about the exam. The degree of pain perceived by all patients was measured 1 and 5 minutes after the procedure using Visual Analog Scale. Results: In the experimental group, 1 minute after the examination, $29.2 \%$ of the patients reported mild pain, $24.7 \%$ moderate pain and $46.1 \%$ severe pain. In the control group, $28.6 \%$ of the patients reported mild pain, $29.6 \%$ moderate pain and $41.8 \%$ severe pain. In the analysis 5 minutes after the examination of the experimental group $60.7 \%$ of the patients reported mild pain, $28.1 \%$ moderate pain and $11.2 \%$ severe pain and the control group $62.3 \%$ of the patients reported mild pain, $26.5 \%$ moderate pain and $11.2 \%$ severe pain. Conclusions: The study was not able to demonstrate the relationship of pain perceived by patients with prior multimedia orientation, thus that, more studies are needed.
\end{abstract}

Keywords: hysteroscopy; pain measurement; anxiety; pain perception; gynecology.

\section{Introduction}

Hysteroscopy has become, in recent years, an excellent propedeutic method in gynecology, being considered the gold standard approach for diagnosis and treatment of intrauterine pathologies. ${ }^{1-4}$ The examination presents advantages compared to Dilatation of the Endocervical Canal and curettage, mainly due to its cost, because it does not require hospitalization and surgical room, and for safety, because it dispenses anesthesia, presenting a low incidence of complications. Moreover, diagnostic hysteroscopy has been more effective in the identification of abnormalities from the endometrial cavity. ${ }^{2,5-7}$

The main indications for this procedure are abnormal uterine bleeding, infertility, repeated abortions, diagnosis and follow-up of endometrial hyperplasia, endometrial cancer staging, identification of foreign bodies, investigation of suspected intrauterine pathologies in other examinations and pre and postoperative control of hysteroscopic surgeries..$^{1,4,7,8}$ The risks of the hysteroscopy realization are extremely rare and consist of bleeding after the examination, intrauterine infection and uterine perforation. These situations can be prevented through the applicability of a good technique and constant supervision by a trained and experienced attendant, in addition to a rigor with asepsis and antisepsis of the materials, professionals and the environment involved in the entire process. ${ }^{1,9}$

Financial support: Fundação de Amparo à Pesquisa do Estado de Minas Gerais - FAPEMIG.

Conflicts of interest: The authors declare no conflicts of interest.

Submitted: Sep. 04, 2019.

Accepted: Nov. 21, 2019.

The study was carry out at HUCMMG, Belo Horizonte, MG, Brasil.

Copyright Pace et al. This is an Open Access article distributed under the terms of the Creative Commons Attribution License, which permits unrestricted use, distribution, and reproduction in any medium, provided the original work is properly cited. 
Its use on a large scale as an outpatient method has some obstacles, among them, the triggered pain mainly by uterine distension during the procedure..$^{10-12}$ Pain and discomfort are the main cause of hysteroscopy failure, which may limit or interrupt the evaluation and even frustrate the patient's return to future controls. ${ }^{8,10,13}$ About $30 \%$ of patients undergoing this procedure without any type of anesthesia refer to feel severe pain, and the procedure performed with saline $0.9 \%$ was less painful than the technique with $\mathrm{CO} 2 .{ }^{14,15}$

The attempts to reduce pain using local anesthesia are usually unsuccessful, sometimes being considered more painful than the procedure itself. The use of analgesics, misoprostol and anti-inflammatory drugs was also not effective for pain relief during the procedure, reducing discomfort only 30 to 60 minutes after exame. ${ }^{1,8,10}$ Thus, the need for anesthesia or analgesia to perform hysteroscopy is still a matter of debate..$^{16-20}$

A review published by Cochrane in 2017 concludes that there are still no studies with good evidence proving the effectiveness of some method for pain relief during outpatient hysteroscopy. ${ }^{21}$ In addiction, it has been documented that surgical procedures can be associated with increased anxiety, this emotional state can lead to psychologic and physiologic responses, such as reduction of pain threshold. ${ }^{22,23}$ Because of that, one hypothesis is that if patients would have a greater clarification about the examination, they could have a reduction of anxiety and even perceive a lower discomfort during hysteroscopy. ${ }^{13,24}$

In this sense, this study aims to evaluate the impact of previous guidance on ambulatory hysteroscopy using multimedia resources (film), in comparison with only verbal orientations, in the intensity of perceived pain by the patient during the procedure without anesthesia.

\section{Method}

Randomized clinical trial performed in the course of hysteroscopy of the post-graduation of minimally invasive gynecology of a teaching hospital in Belo Horizonte, Brazil, between April 11, 2018 and December 18, 2018, aimed only at users of the Unified Health Service. The patients included in the study and the responsible researchers participated in a voluntary and consensual manner and the project was approved by the Research Ethics Committee of the FCMMG in December 2017. Thus, the research did not present a conflict of interest.

\section{Participants}

The study included 187 patients with average age of 50.44 (SD=12.78), submitted to outpatient hysteroscopy with an average duration of 12 minutes. They were all referred for diagnostic hysteroscopy, without contraindications to the exam and voluntarily accepted to participate in the study, through a free and informed consent form (ICF).

The exclusion criteria adopted were: previous performance of hysteroscopy (second look), have already obtained information via multimedia about the procedure or the inconclusion of the exam. The 187 patients were enrolled in the study and randomised into two groups, the experimental group consisted of 89 patients and the control group counted 98 patients.

\section{Materials}

Randomization was performed by means of a mobile application (RandomNumberGenaretor) that generated a random sequence of numbers that indicated whether or not they would watch the video.

The explanatory video ${ }^{25}$ that was shown to the experimental group has 4 minutes and 33 seconds of duration, which consists of a detailed description of the procedure with an easy-to-understand vocabulary. Initially, the video addresses the anatomy of the female reproductive system, followed by an elucidation of the previous and posterior conducts to the examination and the exam itself, by means of schematic figures and images of the procedure. It also presents the main indications and contraindications of the examination and the necessary care for its accomplishment. The video was made by a post-graduation student of minimally invasive gynecology from the same teaching hospital in Belo Horizonte.

The perceived pain intensity was evaluated with a visual analogue scale (VAS) of pain, which consists of a ruler numbered 0 to 10 , with facial expressions varying according to pain degree, the scale is divided into three parts that indicate low $(0,1,2$ or 3$)$, moderate $(4,5$ or 6$)$ and severe pain $(7,8,9$ or 10$)$. The VAS was provided by the hospital and is used routinely in internal studies and procedures.

\section{Procedures}

The experimental group attended the standardized explanatory video that was shown to the patient selected just before the outpatient hysteroscopy was performed. The control group received standardized verbal orientations about the execution of the test. 
All examinations were performed at the outpatient clinic of the hospital by a postgraduate student accompanied by the attendant responsible for the service. The technique of choice was using saline solution (SF 0.9\%) for visualization of the uterine cavity. The postgraduates and the attendants were unaware of which patients had watch the video. In addition, the gynecologist responsible for the examination informed all the steps during its realization and clarified doubts of the patient when requested. All preventive measures regarding the risks of the examination are constantly adopted in the outpatient clinic of the post-graduation of minimally invasive gynecology of the university.

At the time of data collection, it was explained to patients that 0 indicated no pain and 10 the maximum pain already felt by her in life, and so requested that she give a score of 1 to 10 that corresponded to the degree of pain perceived 1 minute after the examination and 5 minutes after the end of this.

\section{Analysis}

The Mann-Whitney test was used to compare means and to test the association between categorical variables, the Chi-square test was used. The analyses were performed in the software R, version 3.4.3.

\section{Results}

In the experimental group, 1 minute after the exam, 29.2\% of the patients reported low pain, $24.7 \%$ moderate pain and $46.1 \%$ severe pain. In the control group $28.6 \%$ of the patients reported low pain, $29.6 \%$ moderate pain and $41.8 \%$ severe pain. In the analysis 5 minutes after the examination of the experimental group $60.7 \%$ of the patients reported low pain, $28.1 \%$ moderate pain and $11.2 \%$ severe pain and the control group $62.3 \%$ of the patients reported low pain, $26.5 \%$ moderate pain and $11.2 \%$ severe pain, as represented in Table 1.

When the analysis was made with the average pain, the experimental group had a mean of 5.57 ( \pm 2.97$) 1$ minute after the exam and of $2.98( \pm 2.81), 5$ minutes after. And the control group of $5.58 \pm(2.94) 1$ minute after the exam and of $3.07 \pm(2.60), 5$ minutes after.

Table 1. Chi-square test for differences of and pain levels $1^{\prime}$ and $5^{\prime}$ after examination

\begin{tabular}{|c|c|c|c|c|}
\hline & \multirow[b]{2}{*}{ Total } & \multicolumn{2}{|c|}{ Group } & \multirow[b]{2}{*}{ P-value ${ }^{Q}$} \\
\hline & & $\begin{array}{l}\text { Experimental } \\
\qquad(n=89)\end{array}$ & $\begin{array}{l}\text { Control } \\
(n=98)\end{array}$ & \\
\hline \multicolumn{5}{|c|}{ Pain level 1 minute after exam } \\
\hline Low & $54(28.88)$ & $26(29.21)$ & $28(28.57)$ & \\
\hline Moderate & $51(27.27)$ & $22(24.72)$ & $29(29.59)$ & 0.740 \\
\hline Severe & $82(43.85)$ & $41(46.07)$ & $41(41.84)$ & \\
\hline \multicolumn{5}{|c|}{ Pain level 5 minutes after exam } \\
\hline Low & $115(61.50)$ & $54(60.67)$ & $61(62.24)$ & \\
\hline Moderate & $51(27.27)$ & 25 (28.09) & $26(26.53)$ & 0.970 \\
\hline Severe & $21(11.23)$ & $10(11.24)$ & $11(11.22)$ & \\
\hline
\end{tabular}

"Chi-square. Categorical variables are represented as "n (\%)".

\section{Discussion}

This study aimed to evaluate whether the instruction would have an effect on perceived pain intensity by the patient during hysteroscopy without anesthesia. Our main hypothesis was that if patients had a greater clarification about the examination with multimedia, they could reduce anxiety regarding their execution and even perceive a lower discomfort during the exam.

The increasing number of hysteroscopy procedure being made in outpatient environment has presented a great propaedeutic advance in minimally invasive gynecology. An analysis of the procedure without anesthesia on one hand is extremely positive, because of the costs and facilitation of access to the procedure. ${ }^{26}$ On the other hand, the perception of the pain by the patients, despite of being considered as a moderate discomfort, but tolerable, must be taken into 
Table 2. Mann-witney test, for comparison between averages of age, duration of examination, and average pain levels

\begin{tabular}{|c|c|c|c|c|}
\hline & \multicolumn{3}{|c|}{ Group } & \multirow[b]{2}{*}{ P-value ${ }^{\mathrm{M}}$} \\
\hline & Total & $\begin{array}{l}\text { Experimental } \\
\qquad(n=89)\end{array}$ & $\begin{array}{l}\text { Control } \\
(n=98)\end{array}$ & \\
\hline Age & $50.44 \pm 12.78$ & $50.16 \pm 13.36$ & $50.66 \pm 12.40$ & 0.977 \\
\hline Exam duration (min) & $12.00 \pm 7.76$ & $11.35 \pm 7.28$ & $12.58 \pm 8.15$ & 0.289 \\
\hline Pain level 5 minutes after exam & $2.98 \pm 2.70$ & $2.88 \pm 2.81$ & $3.07 \pm 2.60$ & 0.408 \\
\hline
\end{tabular}

MMann-Whitney Test. Test Numerical variables are presented as "mean \pm standard deviation".

account by the doctor. ${ }^{13,23,24}$ It is of extreme importance the concern with the tolerance and the discomfort made by the procedure, which many time are not taken into account. ${ }^{17-20,22,27}$

According to Dinz et al. the test could be more tolerable if the patients were instructed in a more detailed way, which was supposed to reduce the anxiety and the expectation regarding the procedure, being this the main hypothesis of the study..$^{13}$ On one hand, the present study showed that the more well-oriented patients presented slightly more pronounced pain rates, when the analysis was made with the percentage. On the other hand, if the categorization had been according to the averages of pain, the result could be different, which may be a justification for the difference of results between groups.

However, analyzing the percentages, the experimental group had a higher percentage of patients with accentuated pain (46.07\%) in comparison to the control group that had a percentage of $41.84 \%$, as shown in Table 1 . Nevertheless, this result is considerate statistically irrelevant, because the $\mathrm{p}$-value found was $0.740(\mathrm{P}<0.05)$. Which leads us to a possible limitation of the research, raising the questioning that the visualization of the video actually would have increase the anxiety, and consequently the pain perceived by the patients. In addition, the explanatory methodology of the video, the moment of its visualization and the sample size may also have influenced the results obtained.

Another important contribution of the research is the percentage of patients from the control group, which refers to have felt severe pain during the examination, which is $41.8 \%$. This value varies considerably from the value of $30 \%$ cited by Julio Cesar et.al. The present study result may have been influenced by the learning curve, because post-graduations students were the examiners and they were practicing how to perform the procedure. This could affect the duration of the exam, that had a standard deviation of 7.76 minutes, as shown in Table 2 and also the variation of technique between the students. In summary, this context could be considered as a learning bias, and this fact may have interfered in the research outcomes, showing the need for new researchers on the subject to elucidate this issue and propose more tolerable alternatives for patients. ${ }^{22}$

\section{Conclusion}

Although there is no relevant statistic association between the way of orientation and the level of pain referred by the patients, the ones that watched the explanative video had a light tendency to feel a little bit more pain.

\section{Acknowledgements}

The Fundação de Amparo à Pesquisa do Estado de Minas Gerais - FAPEMIG, contributed to research development in a relevant way with a scholarship that was a lodging allowance to the research. The Dra. Mônica Bandeira Melo voluntarily contribuited with the explanatory video that was used in the research. The research CAAE: 78478447.4.0000.5134.

\section{References}

1. Teran-Alonso MJ, De Santiago J, Usandizaga R, Zapardiel I. Evaluation of pain in office hysteroscopy with prior analgesic medication: a prospective randomized study. Eur J Obstet Gynecol Reprod Biol. 2014;178:123-7. http://dx.doi.org/10.1016/j.ejogrb.2014.04.030. PMid:24835860.

2. Munro MG, Storz K, Abbott JA, Falcone T, Jacobs VR, Muzii L, et al. AAGL practice report: practice guidelines for the management of hysteroscopic distending media. J Minim Invasive Gynecol. 2013;20(2):137-48. http://dx.doi.org/10.1016/j.jmig.2012.12.002. PMid:23465255. 
3. De Angelis C, Santoro G, Re ME, Nofroni I. Office hysteroscopy and compliance: mini-hysteroscopy versus traditional hysteroscopy in a randomized trial. Hum Reprod. 2003;18(11):2441-5. http://dx.doi.org/10.1093/humrep/deg463. PMid:14585898.

4. Yen CF, Chou HH, Wu HM, Lee C-L, Chang T-C. Effectiveness and appropriateness in the application of office hysteroscopy. J Formos Med Assoc. 2019;118(11):1480-7. http://dx.doi.org/10.1016/j.jfma.2018.12.012. PMid:30611636.

5. Almeida ZMMC, Pontes R, Costa HLFF. Avaliação da dor na histeroscopia diagnóstica por vaginoscopia utilizando-se, como meio de distensão, solução salina à temperatura corporal: Ensaio clínico randomizado. Rev Bras Ginecol Obstet. 2008;30(1):25-30.

6. Hassan A, Wahba A, Haggag $\mathrm{H}$. Tramadol versus Celecoxib for reducing pain associated with outpatient hysteroscopy: a randomized double-blind placebo-controlled trial. Hum Reprod. 2016;31(1):60-6. http://dx.doi.org/10.1093/humrep/dev291. PMid:26621854.

7. Salazar CA, Isaacson KB. Office operative hysteroscopy: an update. J Minim Invasive Gynecol. 2018;25(2):199-208. http://dx.doi. org/10.1016/j.jmig.2017.08.009. PMid:28803811.

8. Issat T, Beta J, Nowicka MA, Maciejewski T, Jakimiuk AJ. A randomized, single blind, placebo-controlled trial for the pain reduction during the outpatient hysteroscopy after ketoprofen or intravaginal misoprostol. J Minim Invasive Gynecol. 2014;21(5):921-7. http://dx.doi.org/10.1016/j.jmig.2014.04.006. PMid:24768981.

9. Cooper NA, Smith P, Khan KS, Clark TJ. Vaginoscopic approach to outpatient hysteroscopy: a systematic review of the effect on pain. BJOG. 2010;117(5):532-9. http://dx.doi.org/10.1111/j.1471-0528.2010.02503.x. PMid:20374594.

10. Bakour SH, Jones SE, O'Donovan P. Ambulatory hysteroscopy: evidence-based guide to diagnosis and therapy. Best Pract Res Clin Obstet Gynaecol. 2006;20(6):953-75. http://dx.doi.org/10.1016/j.bpobgyn.2006.06.004. PMid:17116420.

11. Cooper NA, Smith P, Khan KS, Clark TJ. A systematic review of the effect of the distension medium on pain during outpatient hysteroscopy. Fertil Steril. 2011;95(1):264-71. http://dx.doi.org/10.1016/j.fertnstert.2010.04.080. PMid:20576262.

12. Bradley LD. Overview of hysteroscopy. Massachusetts: UpToDate; 2010.

13. Diniz DBFQ, Depes DB, Santos AMG, David SD, Yatabe S, Lopes RGC. Avaliação da dor na histeroscopia diagnóstica ambulatorial com gás. Einstein. 2010;8(1):24-8. http://dx.doi.org/10.1590/s1679-45082010ao1342. PMid:26761748.

14. Rosa e Silva JC, Nascimento AD, Silva ACJSR, Poli Neto OB, Barbosa HF, Reis FJC, et al. Uso do spray de lidocaína em histeroscopia diagnóstica. Rev Bras Ginecol Obstet. 2007;29(4):181-5. http://dx.doi.org/10.1590/S0100-72032007000400003.

15. Cicinelli E. Histeroscpy without anestesia: review of recente literature. J Minim Invasive Gynecol. 2010;17(6):703-8. http://dx.doi. org/10.1016/j.jmig.2010.07.003. PMid:20955981.

16. Diniz DBFQ, Depes DDB, Pereira AMG, David SD, Lippi UG, Baracat FF, et al. Avaliação da dor em histeroscopia ambulatorial: comparação entre duas técnicas. Rev Bras Ginecol Obstet. 2010;32(1):26-32. http://dx.doi.org/10.1590/S0100-72032010000100005. PMid:20209259.

17. Luscombe KS, McDonnell NJ, Muchatuta NA, Paech MJ, Nathan EA. A randomised comparison of parecoxib versus placebo for pain management following minor day stay gynaecological surgery. Anaesth Intensive Care. 2010;38(1):141-8. http://dx.doi. org/10.1177/0310057X1003800123. PMid:20191790.

18. Hassan A, Haggag $\mathrm{H}$. Role of oral tramadol $50 \mathrm{mg}$ in reducing pain associated with outpatient hysteroscopy: a randomised doubleblind placebo-controlled trial. Aust N Z J Obstet Gynaecol. 2016;56(1):102-6. http://dx.doi.org/10.1111/ajo.12431. PMid:26817525.

19. Fouda UM, Gad Allah SH, Elshaer HS. Optimal timing of misoprostol administration in nulliparous women undergoing office hysteroscopy: a randomized double-blind placebo-controlled study. Fertil Steril. 2016;106(1):196-201. http://dx.doi.org/10.1016/j. fertnstert.2016.03.022. PMid:27037462.

20. Floris S, Piras B, Orrù M, Silvetti E, Tusconi A, Melis F, et al. Efficacy of intravenous tramadol treatment for reducing pain during office diagnostic hysteroscopy. Fertil Steril. 2007;87(1):147-51. http://dx.doi.org/10.1016/j.fertnstert.2006.05.072. PMid:17081540.

21. Ahmad G, O'Flynn H, Attarbashi S, Duffy JM, Watson A. Pain relief for outpatient hysteroscopy. Cochrane Database Syst Rev. 2010;(11):CD007710. http://dx.doi.org/10.1002/14651858.CD007710.pub3. PMid:21069695.

22. Angioli R, De Cicco Nardone C, Plotti F, Cafà EV, Dugo N, Damiani P, et al. Use of music to reduce anxiety during office hysteroscopy: prospective randomized trial. J Minim Invasive Gynecol. 2014;21(3):454-9. http://dx.doi.org/10.1016/j.jmig.2013.07.020. PMid:23962572.

23. White JM. Music as intervention: a notable endeavor to improve patient outcomes. Nurs Clin North Am. 2001;36(1):83-92. PMid:11342404.

24. Lau WC, Ho RY, Tsang MK, Yuen PM. Patients acceptance of outpatient hysteroscopy. Gynecol Obstet Invest. 1999;47(3):191-3. http://dx.doi.org/10.1159/000010092. PMid:10087415.

25. YouTube. Informativo sobre videohisteroscopia ambulatorial [Internet]. 2017 [cited 2019 Nov 26]. Available from: https://youtu. be/TfRhbaXtzol

26. Vilos GA, Abu-Rafea B. New developments in ambulatory hysteroscopic surgery. Best Pract Res Clin Obstet Gynaecol. 2005;19(5):72742. http://dx.doi.org/10.1016/j.bpobgyn.2005.06.012. PMid:16126460.

27. Allen RH, Micks E, Edelman A. Pain relief for obstetric and gynecologic ambulatory procedures. Obstet Gynecol Clin North Am. 2013;40(4):625-45. http://dx.doi.org/10.1016/j.ogc.2013.08.005. PMid:24286993. 


\section{*Correspondence}

Walter Antônio Prata Pace

PHD Pace Hospital

Av. do Contorno, 7851, Cidade Jardim

CEP 30180-112, Belo Horizonte, MG, Brasil

Tel.: +55 (31) 99307-0382

E-mail: walterpace@ig.com.br

\section{Authors information}

WAPP - Master in Human Reproduction at Assistant Ètranger from Paris V René Descartes University and PhD in Gynecology at UFRJ, adjunct PhD Professor of Gynecology and Obstetrics at FCMMG, general coordinator of the Minimally Invasive Gynecology Graduate Program at HUCMMG; ALLP - Medical student at PUCMG; AAM - Medical student at FCMMG; FANP - PhD and Master in Women's Health by the Graduate Program of the Medical School of UFMG, professor at the Minimally Invasive Gynecology Graduate Program at HUCMMG; GLP - Medical student at FCMMG; JOAFJ - PhD and Master in Gynecology, Obstetrics and Mastology from UNESP, professor at the Minimally Invasive Gynecology Graduate Program at HUCMMG.

\section{Authors contribution}

ALLP, AAM and GLP were in charge of data collection and analysis, interpretation of data, and writing of the article. WAPP, FANP and JOAFJ were responsible for conception and design of the research, reviewing the intellectual content, and final approval of the version to be published. 